\title{
ГЕНЕЗИС ПРИНЦИПУ ЗАБОРОНИ ЗЛОВЖИВАННЯ ПРАВОМ ВІД РИМСЬКИХ ЧАСІВ ДО СУЧАСНОГО ВТІЛЕННЯ В ПРАКТИЦ ССПЛ
}

\author{
КОТЬКО Марія Ігорівна - факультет Інституту підготовки кадрів для \\ органів юстиції України Національного юридичного університету імені Ярослава \\ Мудрого
}

ORCID ID: https://orcid.org/0000-0002-1460-2200

УДК 340.132

DOI 10.32782/EP.2020.3.4

\begin{abstract}
Приниип заборони зловживання правом відіграє важливу роль як регулятор правомірной поведінки, спрямований на ефективне здійснення суспільних відносин. У статті досліджено генезис поняття зловживання правом від римсъких часів до сучасного закріплення в нормативно правових актах. Втілення сучасних тендениій зловживання правом е судовій практииі Европейсъкого Суду з прав людини. Проведено аналіз основних формм, видів та правових наслідків зловживання правами тощо. Систематизовано нормативне втілення заборони зловживання правом е законодавстві Украӥни та зарубіжних краӥна. Виявлено основні тенденциї розвитку зловживання правом та методи його запобіганню. Запропоновано шляхи вдосконалення та гармонізащї концепиій зловживання правом відповідно до зарубіжного досвіду в судових практиках.

Ключові слова: зловживання правом, шикана, римське право, правопорушення, відповідальність, нормативно правовий акт, заборона, судова практика.
\end{abstract}

\section{Постановка проблеми}

Актуальним і спірним на сьогодні залишається визначення та кваліфікування поняття зловживанням правом На сучасний розвиток становлення поняття зловживання правом вплинулf відсутність узгоджених підходів до розуміння сутності зловживання правом, особливостей виявлення та припинення окремих його проявів з початку формування концепції зловживання правом, що зумовило проблеми встановлення факту порушення заборони зловживання правом е сучасній судовій приктиці.

\section{Мета статті}

Головною метою цієї роботи є дослідження генезесу поняття зловживання правом з часів римського законодавства до сучасного закріплення в нормативно-правових актах, застосування принципу зловживання правом у судовій практиці, формування принципів щодо запобігання зловживання правом е суспільстві.

Аналіз останніх досліджень і публікацій

Питатня щодо зловживання правом порушивали ще 3 часів римського права. Питанням сутності та кваліфікації зловживання правом займалися такі відомі юридичній науці вчені, як: Агарков М. М., Бару М. І., Братусь С. М., Горбась Д. В., Грібанов В. П., Зайцева С. Г., Іоффе О. С., Калюжний Р. А., Курбатов А. Я., Малєін Н. С., Маліновський О. О., Муранов А. І., Покровський Й. О., Поротікова О. А., Рясенцев В. А., Самойлова М. В., Тимошенко В. І., Янко Г. Янев та деякі інші.

Виклад основного матеріалу

Незважаючи на наявність певних теоретичних напрацювань у сфері зловживання правами, на сьогодні залишаються невирішеними питання щодо поняття, форм, видів та правових наслідків зловживання правами тощо. Одним із наслідків є виник- 


\section{Теорія, історія держави і права, конституційне право}

нення проблемних питань при кваліфікації поведінки особи як зловживання правами, визначення правових наслідків діяння і застосування відповідних санкцій до осіб, що зловживають правами.

Спірність визначення поняття зловживання правом бере свій початок $з$ права в Римській імперії. 3 одного боку, римське право сформовано на принципі абсолютної свободи дій, згідно з яким суб'єкт у межах своїх прав може здійснювати будь-які дії, відображає принцип «qui iure suo utitur, nemini facit iniuriam» (3 лат.: хто здійснює своє право, той не утискає прав інших) [1]. Вплив на формування правового феномену зловживання правом мав рабовласницький устрій суспільства, у якому вся влада та необмеженість у користуванні правами надавалися рабовласникам, а це означало, що поняття зловживання правом не існувало[2]. Aле з розвитком суспільних відносин з'явилися випадки, коли здійснення особою іiі суб'єктивного права передбачало не лише правомірну мету, але i мету заподіяння шкоди інший особі. Тому в процесі формування права з'являється необхідність охарактеризувати таку неправомірну поведінку як зловживання правом, та закріпити шляхи їі запобігання.

Римське право ще не оперувало поняттям зловживання правом і не закріплювало пряму заборону зловживання правом як загальний принцип права[3], а лише зазначало окремі за своїм характером випадки неправомірного використання права на шкоду іншим. Так, юристи зазначали: «nullus videtur dolo facere, qui jure suo utitur» («ніхто не робив цього з вами, той, хто користується своїми законними правами») (Гай); «qui jure suo utitur neminem laedit» («не ображає нікого той, хто використовує своє право») (Павел), «summum ius - summa injuzia» («доведене до абсурду право - гранична несправедливість») (Ульпиан); «male enim nostro iure uti non debemus»(«ми не повинні погано користуватися своїм правом») (Гай); «сontra legem facit, qui id facit, quod lex prohibet; in fraudem vero, qui salvis verbis legis sententiam eius circumvenit» («надходить проти закону той, хто робить заборонене законом; надходить в обхід закону той, хто, зберігаючи слова закону, обходить його сенс») (Павел) [3].
Хоча, незважаючи на те, що самого терміна «зловживання правом» або подібного до нього давньоримські юристи не сформулювали, у їхніх працях можна знайти приклади діянь, які, по суті, є зловживанням правом, а вчинення їх тягло відповідні правові наслідки [4]. Так, у «Дигестах вказівки Цельса» зазначалось, що «годі було надавати поблажливості злобі, якщо, наприклад, ти захочеш зчистити гіпсові прикраси зі стін або картини, нічого від цього не отримуючи, але лише досаждуючи мені» [2]. Тому в римському праві все ж таки існували деякі обмеження суб'єктивного права, коли вони використовувались 3 виключної мети завдати шкоди іншим. Закон вказував на необхідність використання приватних прав обачно(civiliter modol).

Схожий підхід до проблеми визначення зловживання правом мав давньоримський юрист Гай. 3 одного боку, виходячи 3 принципу повної свободи використання права, він зазначав: "Nullus videtur dolo faure, qui jure suo utitur». («Ніхто не вважається тим, хто робить зловмисно, якщо він користується належним йому правом»). Але з іншого боку, наголошував на розумному використанні субєктивних прав у межах власних інтересів і потреб «Male enim nostro iure uti non debemus; qua ratione et prodogis interdicitur bonorum suorum administration» (Гай. 1.53). «Імператор, запитаний управителями провінцій, розпорядився, щоб якщо виявиться, що лютість панів є нестерпним, то панове змушені б продавати своїх рабів. І добре зробив - ми не повинні погано користуватися своїм правом; у силу цього підстави і марнотратником забороняється управління їх майном» [5].

У Римському законодавстві знайшло своє закріплення заборона зловживання правом при здійснення права власності, відоме римлянам, як заборона шикана. Наприклад, у Кодифікації Юстініана описується заборона шикани, як заборона зведення власником міського ділянки високої стіни 3 єдиною метою позбавити сусідів виду на море[6].у «Дигестах вказівку Цельса» також існували приклади заборони шикани. Наприклад, неприпустимим вважалося копання колодязя на своїй ділянці з винятковою метою позбавити води колодязь сусіда. 
Незважаючи на те, що саме поняття зловживання правом не знайшло свого закріплення в римському праві, ідеї, які були закладені римськими юристами щодо існування феномену зловживання правом, знайшли своє відображення в цивільному законодавстві зарубіжних країн.

Уперше закріплення принципу заборони зловживання правом з'явилося у Франції в епоху Французької революції. Стаття 4 Декларації прав людини і громадянина 1789 рік (далі-Декларація) встановлювала: «Свобода полягає в можливості робити все, що не шкодить іншому: отже, здійснення природних прав кожної людини обмежено лише тими межами, які забезпечують іншим членам суспільства користування тими ж правами. Межі ці можуть бути визначені тільки законом». Стаття 11 Декларації закріплювала найважливіший принцип: «Вільне висловлювання думок та точок зору є одними з найцінніших прав людини; тому кожен громадянин може вільно висловлюватися, писати, друкувати, відповідаючи лише за зловживання цією свободою у випадках, передбачених законом» [7].

Наступним закріпленням принципу заборони зловживання правом на конституційному рівні було Пруське Земське Уложення 1794 року( далі- Уложення), яке встановило заборону шикана, як однієї форми зловживання правом, тим самим зробивши вплив на подальший розвиток концепції зловживання правом у правовій науці. Так, у параграфі 28 Уложення обумовлювалось питання зловживання власністю “таке користування власністю, яке, за своєю суттю, може мати виключно лише те призначення, щоб заподіяти кому-небудь неприємність"[8]. У параграфі 37 Титулу 6 Уложення як зловживання правом зазначалось, що неправомірною є поведінка особи, котра “ 3 багатьох способів правореалізації ... умисно, $з$ наміром заподіяти шкоди ближньому, вибирала для останнього шкідливий споciб" [9].

В Уложенні вперше було встановлене покарання за зловживання правом. Так, у параграфах 72 та 107 Уложення була встановлена відповідальність за зловживання правом, яка полягала в позбавленні приві- леїв, використаних на шкоду державі або громадян, і відшкодування заподіяних збитків.

Подальше нормативне закріплення заборони зловживання правом знайшло своє відображення в Цивільному уложенні Нiмеччини 1896 році (далі ЦУН). А саме, відповідно до параграфу 226 ЦУН «не допускається здійснення права, якщо метою такого здійснення може бути тільки заподіяння шкоди іншому». [11]. Впровадження принципу заборони зловживання правом у законодавство, спричинило появу невизначеності щодо встановлення меж добросовісного використання права та його зловживання.

Утвердження принципу захисту прав людини як пріоритету на сучасному етапі розвитку суспільства сприяло закріпленню заборони зловживання правом на міжнародному рівні. Зокрема, Европейської Конвенції з прав людини у статті 17, яка проголошує заборону зловживання правами «жодне 3 положень цієї Конвенції не може тлумачитись як таке, що надає будь-якій державі, групі чи особі право займатися будь-якою діяльністю або вчиняти будь-яку дію, спрямовану на скасування будь-яких прав і свобод, визнаних цією Конвенцією, або на їх обмеження в більшому обсязі, ніж це передбачено в Конвенції».

Положення 17 статті Конвенції спрямоване на забезпечення демократичними засобами боротьби з діями та діяльністю, які знищують або неналежним чином обмежують основні права і свободи незалежно від того, чи ці дії або діяльність здійснюються «державою», «групою» або «особою», тим самим розділяючи адресатів[12]. За період існування ЕСП $\curlywedge$ було подано і розглянуто 118 скарг 3 порушенням 17 статті. 3 них 1 справа, у якій поєднано 17 статтю зі статтею 5 Конвенції(Право на свободу та особисту недоторканність), 4 зі статтею 6(Право на свободу та особисту недоторканність), 1 зі статтею 7(Ніякого покарання без закону), 4 зі статтею 9(Свобода думки, совісті і релігіï), 15 за статтею 11(Свобода зібрань та об'єднання), 1 за статтею 13(Право на ефективний засіб юридичного захисту), 6 зі статтею 14(Заборона дискримінації), 1 зі статтею 


\section{Теорія, історія держави і права, конституційне право}

35(Умови прийнятності). Найбільша кількість справ 64, у яких поєднано порушення статті 17 зі статтею 10(Свобода вираження поглядів). У 27 справах Суд відмовився застосовувати статтю 17 до заявника, розглянувши всі деталі справи, і дійшовши висновку, що порушення 17 статі не відбувалося, у інших справах скарги заявників відповідно до наведених положень були відхилені як несумісні ratione materiae 3 положеннями Конвенції.

Стосовно адресатів статі 17 розрізняють державу та групу або особу. За адресатом держави у практиці ЄСП $\Lambda$ було подано 15 скарг, у 14 з яких не було визначено Судом порушення 17 статті. За адресатом групи або особи було розглянуто 110 справ, в 27 з яких не було визначено Судом порушення 17 статті.

Вперше визнання Судом зловживання правом влади на підставі статті 17 Конвенції було у справі “Мозер проти Молдови та Роciї”, заявник скаржився на порушення статті 17 Конвенції обома державами-відповідачами через їхню терпимість до незаконного режиму, встановленого в “Молдавській Республіці Придністров’я”, яка не визнавала жодних прав, викладених у Конвенції[13]. Розглянувши всі деталі справи, Суд постановив, що держава діяла у спосіб, спрямований на знищення будь-якого з цих прав і свобод або обмеження їх у більшому обсязі, ніж це передбачено Конвенцією. До цього часу жодна держава не була засуджена на цій підставі[13].

Винесення рішення щодо зловживання правом на підставі врахування впливу оспорюваної поведінки, було у справах «Рой ТВ А/С» проти Данії» та «Лерой проти Франції», Судом було враховане саме мету та характер дій заявників. Так, у справі «Рой ТВ А/С» проти Данії», у якій у 2012 році компанія «Рой ТВ A/C» була засуджена за те, що вона сприяла терористичній діяльності Робочої партії Курдистану за допомогою своїх телевізійних програм, що транслювалися в період з 2006 по 2010 рік. Внутрішньодержавні суди відзначили, що Робоча партія Курдистану, яка входила в списки терористичних організацій у Европейському союзі, Канаді, Сполучених
Штатах Америки, Австралії та Сполученому Королівстві, здійснювала або мала намір вчинити терористичні акти за змістом Кримінального кодексу Данії. Суд дійшов висновку, що компанія-заявник, яка керувала телевізійним каналом, була визнана винною у сприянні терористичній організації РПК (Робітничої партії Курдистану) у своїх програмах. Їй був призначений штраф, і вона була позбавлена ліцензії на мовлення. Незважаючи на те, що заявник подав скаргу на порушення статті 10 Конвенції (свобода вираження поглядів), на думку Суду скарга компанії-заявника відповідно до статті 17 не передбачала захисту, наданого статтею 10, з урахуванням впливу і характеру оскаржених програм, які були розповсюджені серед широкої аудиторії та містили підбурювання до насильства та підтримку терористичної діяльності i, таким чином були безпосередньо пов'язані з запобіганням тероризму, питанням, яке було першорядним у сучасному європейському суспільстві. Врахувавши саме характер і мету впливу розповсюдженної інофрмації, заява була відхилена як несумісна ratione materiae 3 положеннями Конвенції[14].

У справі «Лерой проти Франції» заявник, карикатурист, був засуджений за співучасть у потуранні тероризму у зв'язку з публікацією малюнка, який зображував напад на будівлі Всесвітнього торгового центру 3 написом: «Ми всі мріяли це ... Хамас зробив це». Натомість порівняно зі справою «Рой ТВ A/С» проти Данії Суд відмовився застосовувати статтю 17 на наступних підставах. По-перше, основне посилання, яке заявник намагався передати - підтримка і прославлення насильницького знищення американського імперіалізму - не було запереченням фундаментальних прав і його було неможливо зрівняти 3 расистськими, антисемітськими або ісламофобськими зауваженнями, які безпосередньо протистояли цінностям, які підкріплювали Конвенцію. Подруге, зображення та супровідний напис не обгрунтовували терористичні акти настільки однозначно, щоб втрачати захист статті 10 Конвенції. Врахувавши мету і характер посилання, Суд у кінцевому підсумку не виявив жодного порушення цього положення 
з урахуванням термінів публікації (лише за два дні після нападу), іï вплив на політично чутливий регіон і необхідність того, щоб органи влади були пильними до ризику посилення насильства[15].

На рішення стосовно порушення заборони зловживання правом впливає врахування важливості контексту, у справі, що розгладається. Так, у справах «М'Бала М'Бала проти Франції» та «Вайнай проти Угорщини» Судом за допомогою ретельного вивчення контексту було винесено рішення щодо питання порушення статті 17. У «М'Бала М’Бала проти Франції» (ріш.) заявник, комедійний актор, який брав участь у політичній діяльності, був засуджений за своє шоу під час якого він запросив глядачів аплодувати «від душі» його гостю, професору вищого навчального закладу, добре відомому за його нігілістьскі погляди. Потім заявник покликав актора, який був одягнений в одяг, який був описаний як «одяг світла» - кілька смугастих піжам, що нагадували одяг, який носили єврейські в’язні, 3 вишитою жовтою зіркою 3 надписом «єврей» - для того, щоб вручити професору «нагороду за рідке відвідування і нахабство». Нагорода отримала форму свічників 3 трьома розгалуженнями 3 яблуком на кожній гілці. У ключовій позиції, наданій появі гостя та принижуючому зображенні євреїв-жертв депортації, який зіткнувся 3 людиною, яка спростовувала їх винищення, Суд побачив демонстрацію ненависті та антисемітизму та підтримку заперечення Голокосту. Суд постановив, що Відверта демонстрація ненависної і антисемітської позиції, замаскована під художній витвір, не може бути уподібнена 3 формою розваги, хоча й сатиричною або провокаційною, якій би був наданий захист статті 10. Вона була такою ж небезпечною як і повноцінний і різкий напад, і тому обумовила необхідність застосування статті 17 (§§ 39-40). Заява була відхилена як несумісна ratione materiae 3 положеннями Конвенції[15].

Натомість у справі «Вайнай проти Угорщини» заявник був засуджений за носіння п’ятикутної червоної зірки на куртці під час санкціонованої демонстрації. На думку
Суду заява не складала зловживання правами для цілей статті 17. По-перше, не було продемонстровано, що заявник висловив презирство до жертв тоталітарного режиму. По-друге, незважаючи на те, що масові порушення прав, які були вчинені під час комунізму, дискредитували його символічну цінність, червона зірка також символізувала міжнародний робітничий рух, який боровся за більш справедливе суспільство, а також деякі правові політичні партії, які діяли у різних державах. По-третє, уряд не продемонстрував, що виключно носіння червоної зірки складало небезпечну тоталітарну пропаганду, особливо розглядаючи його у світлі того факту, що заявник зробив це на законно організованій мирній демонстрації як віце-президент зареєстрованої лівої політичної партії, у якого не було жодних відомих намірів брати участь у політичному житті Угорщини в порушення верховенство права. У кінцевому підсумку Суд виявив порушення статті 10 з урахуванням нерозбірливого характеру i дуже широкого обсягу заборони використання тоталітарних символів[16].

\section{Висновки і пропозиції}

Тобто, проаналізувавши вищенаведене, можна зробити висновок, що поява і розвиток поняття зловживання правом було викликано ускладненням суспільних відносин. Метою заборони зловживання правом було ліквідування перешкод до злагодженого функціонуванням правової системи, запобігання виникнення випадків, коли здійснення суб'єктивного права особою мало мету заподіяти шкоду іншій особі. Але залишаються проблеми, пов'язані з практичним застосування принципу заборони зловживання правом, якій знаходять своє відображення в сучасній практиці ЄСП А. Проблема полягає у визначенні тонкої грані між використанням особою суб'єктивних прав і зловживання правом. На прикладі вище згаданих справ, вплив на рішення Суду мала мета та характер дій заявників та врахування важливості контексту. Важливо зробити більш чітке розмежування між двома інститутами права. 


\section{Теорія, історія держави і права, конституційне право}

\section{Аітература}

1.Потапенко С. В. О злоупотреблен и нравом на свободум массовой информации . - М.: Закон и право. - $\Lambda>2$ 10. - С . 34 -3 7 .

2.D. 39.3.1.12. Римское частное право: учебник / Под ред. И. Б. Новицкого иИ. С. Перетерского. - С. 50.

3.Римское частное право: Учебник /Под редакцией И.Б.Новицкого, И.С.Перетерского. - М.: Издательство «Юристъ», 1996. - 544 с.

4. Римскоечастноеправо: Учебн./Подред. проф. И. Б. Новицкого и проф. И.С. Перетерского. - М.: Юриспруденция, 1999.-512 с.

5. Цит. по: Римское частное право: учебник / Под ред. И. Б. Новицкого и И. С. Перетерского. - М., 2000. - С. 49-50.

6. Дождев Д. В. Римское частное право. - М.: Юриспруденция , 2003. - 784 с

7. Конституційне законодавство зарубіжних країн: Хрестоматія: Навч. посібн. / Упоряд. В. О. Ріяка, К. О. Закоморна. - К.: Юрінком Інтер, 2007. - 384 с.

8. Доманажко В. Отвествиность за вред, причриненній путем злоупотребления правом// Ученые записки Казанскогг университета. Кн. 5.- М., 1913.

9. Малышев К.И. Курс гражданского судопроизводства. - Том первый. - 2-е изд., испр. и доп.,- С.- Петербург: Типография М. - М. Стасюлевич, 1876. - 444c. - с 124

10. Конституційне законодавство зарубіжних країн: Хрестоматія: Навч. посібн. / Упоряд. В. О. Ріяка, К. О. Закоморна. - К.: Юрінком Інтер, 2007. - 384 с.

11. Guide on Article 17 of the European Convention on Human Rights URL.: https:// www.echr.coe.int/Documents/Guide_Art_17_ ENG.

12. CASE OF MOZER v. THE REPUBLIC OF MOLDOVA AND RUSSIA URL.: http:// hudoc.echr.coe.int/eng?i=001-161055. (Дата звернення 23/02/2016)

13. SECOND SECTION DECISION. (Application no. 24683/14) ROJ TV A/S against Denmark URL.: http://hudoc.echr. coe.int/eng?i=001-183289 . (Дата звернення 17/04/2018)

14. FIFTH SECTION CASE OF LEROY v. FRANCE (Application no 36109/03) URL.:
The principle of prohibition of abuse of rights plays an important role as a regulator of lawful behavior, aimed at the effective implementation of public relations. The article examines the genesis of the concept of abuse of law from Roman times to modern enshrinement in regulations. Implementation of current trends in abuse of law in the case law of the European Court of Human Rights. The analysis of the main forms, types and legal consequences of abuse of rights, etc. is carried out. The normative implementation of the prohibition of abuse of rights in the legislation of Ukraine and foreign countries is systematized. The main trends in the development of abuse of rights and methods of its prevention are identified. Ways to improve and harmonize the concept of abuse of law in accordance with foreign experience in judicial practice are proposed. Despite the existence of certain theoretical developments in the field of abuse of rights, today the issues concerning the concept, forms, types and legal consequences of abuse of rights, etc. remain unresolved. One of the consequences is the emergence of problematic issues in the qualification of a person's behavior as an abuse of rights, determining the legal consequences of the act and the application of appropriate sanctions to persons who abuse their rights. the emergence and development of the concept of abuse was caused by the complication of social relations. The purpose of the prohibition of abuse of rights was to eliminate obstacles to the functioning of the legal system, to prevent the occurrence of cases where the exercise of a subjective right by a person was intended to harm another person. But problems remain with the practical application of the principle of non-abuse of rights, which is reflected in modern jurisprudence.

http://hudoc.echr.coe.int/eng?i=001-88657 (Дата звернення 02/10/2008 )

15. FIFTH SECTION DECISION (Application no. 25239/13 Dieudonné M'BALA M'BALA against France URL.: http://hudoc. echr.coe.int/eng?i=001-160358 (Дата звернення 20/10/2015)

16.CASE OF VAJNAI v. HUNGARY (Application no. 33629/06) URL.: http://hudoc. echr.coe.int/eng?i=001-87404 (Дата звернення 08/07/2008) 